TITLE:

\title{
CONTRIBUTIONS TO JAPANESE ASCIDIAN FAUNA XXIII. -ON BOTRYLLOIDES VIOLACEUS MARGINATUS TOKIOKA, 1967-
}

\section{$\operatorname{AUTHOR}(\mathrm{S}):$}

Tokioka, Takasi

\section{CITATION:}

Tokioka, Takasi. CONTRIBUTIONS TO JAPANESE ASCIDIAN FAUNA XXIII. -ON BOTRYLLOIDES VIOLACEUS MARGINATUS TOKIOKA, 1967-. PUBLICATIONS OF THE SETO MARINE BIOLOGICAL LABORATORY 1968, 16(2): 141-145

\section{ISSUE DATE:}

1968-09-25

URL:

http://hdl.handle.net/2433/175538

RIGHT: 


\title{
CONTRIBUTIONS TO JAPANESE ASCIDIAN FAUNA XXIII. ON BOTRYLLOIDES VIOLACEUS MARGINATUS TOKIOKA, 1967'
}

\author{
TAKASI TOKIOKA
}

Seto Marine Biological Laboratory

With 1 Text-figure

During the 1965 biological survey of the reef coral area of Kamaé Bay on the .east coast of Kyûsyû Island planned by Mr. T. UÉDA, the president of the Ôita Marine Palace, and sponsored by that apuarium, I thought I heard Mr. Ch. Araga speaking of his finding of a very prominent compound ascidian which showed very distinct bright orange systems fringed with dark brownish colouration. This reminded me in a moment of the botryllid, Botrylloides violaceus marginatus TokıokA, of which I observed some live specimens on the coral reefs of the Palau Islands in 1940 and then examined two preserved colonies from the same locality at the U.S. National Museum in 1957. Later, Mr. Ch. Araga observed some colonies of a similar ascidian while he was diving in the vicinity of Seto at the places exposed to the ocean water. Unfortunately, however, I had had no chance to obtain and actually examine any Japanese specimen of this ascidian.

In June 1966, the government of Wakayama Prefecture held a preliminary survey - of the promised marine park area along the southern coast of Kii Peninsula. The -survey was carried out under the leadership of Dr. T. TAmura, the director of Japan Society of Nature Conservation at that time, and the biological part, which was -evidently the most important part of the survey, was partaken by members of the Seto Marine Biological Laboratory. On the 21 st, while we were working around Zi-noKurosima, an islet in the district of Susami about $30 \mathrm{~km}$ southeast from the laboratory, a very beautiful compound ascidian was collected from the rocky shore on the land side of the islet. The ascidian was bright reddish orange and systems were defined very clearly by the dark purplish-brown margins on the colony. There are two colonies: one is much smaller, $22 \mathrm{~mm} \times 15 \mathrm{~mm}$ in extent and about $4 \mathrm{~mm}$ in thickness, while the other forms a very complicatedly lobated mass of about $65 \mathrm{~mm} \times 60 \mathrm{~mm}$ in extent at the base of the brown alga, Eckloniopsis radicosa (KJELlman) Okamura. It

1) Biological Studies of the Reef Coral Area of Japanese Main Islands, No. 2 and Contributions from the Seto Marine Biological Laboratory, No. 490.

Publ. Seto Mar. Biol. Lab., XVI (2), 141-145, $1968 . \quad$ (Article 12) 
is very hard to show how the thickness of the larger colony is, though it is possibly about. $4 \mathrm{~mm}$. The system on the smaller colony is very distinct and consists of 121 zooids. (Text-fig. 1 A); even on the larger colony the systems are clearly discernible in some parts.

In examining the structure of zooids closely, I was much impressed by the fact that some zooids are provided with so many stigmatal rows and superficially resemble those of Botrylloides tyreum HERDMAN. Therefore, it will never be only the repetition. to give the description of the specimens here referred to, rather it will be of a great. necessity in order to confirm the identification of the ascidian under consideration with Botrylloides violaceus marginatus and to make the outline of this subspecies clearer.

\section{Botrylloides violaceus marginatus ТокІокА, 1967}

Tокıка 1967: U.S. Nat. Mus. Bull. 251, pp. 160-162, fig. 64.

The test is hard gelatinous, nearly colourless and transparent; the surface is smooth and free from any foreign materials. Systems are very distinct, elongate, and of a complicated configuration. The peripheral area is furnished with a number of ampullae which are pale to dark purplish brown in a preserved state. The general appearance and the colouration of live specimens are given already in the introductory section.

Zooids are elongate, 3.5 to $4.0 \mathrm{~mm}$ in length, situated obliquely to perpendicularly. The branchial aperture round and without any regular lobation along the margin. The atrial aperture is a large cleft of the mantle on the dorsal side in the anterior half to the middle of the body. Generally, the anterior lobe of the atrial aperture is. not protruded out beyond the posterior one to form an atrial languet. The apical wall of the branchial sac, namely the area surrounding the branchial aperture, is. darkly pigmented in preserved specimens, while other parts of the body, especially the anterior side of the anterior lobe of the atrial aperture is devoid of any heavy pigmentation. And such a pigment distribution results in the characteristic colour pattern of systems in live specimens. The alimentary organs occupy only a small part near the posterior end of the branchial sac; only 2-3 stigmatal rows on the left side are covered by them and the most part of the stomach is exposed out of the rear end of the branchial sac. Two fascicular vessels are issued from the dorsal sidenear the posterior end of the body, at the level of the bottom of the second intestinalt loop on the left and at the level of the junction between the oesophagus and the: stomach on the right side.

Stigmatal rows in examined zooids fluctuate between 15(right)-16(left) and. 18 (on both sides); usually one more row on the left side. The second row never reaches dorsally the median line. The anus is plainly margined and attached to the 13 th to 16 th transverse vessel; more posteriorly in zooids with more numerous stigmatal rows so that generally two or three rows are seen posterior to the level of the anus; 
stigmata in the last row may be rudimentary. There are about 15 stigmata in each row on respective sides; they are distributed between the three inner longitudinal vessels as-dorsal lamina 4-5 (1) 2 (1) 1-2 (1) 5 endostyle-near the middle of the branchial sac on the right side in a certain examined zooid. Tentacles 8,4 larger and 4 smaller. The ciliated groove is an oval opening.

The stomach has 10 longitudinal plications exclusive of typhlosole, the pyloric
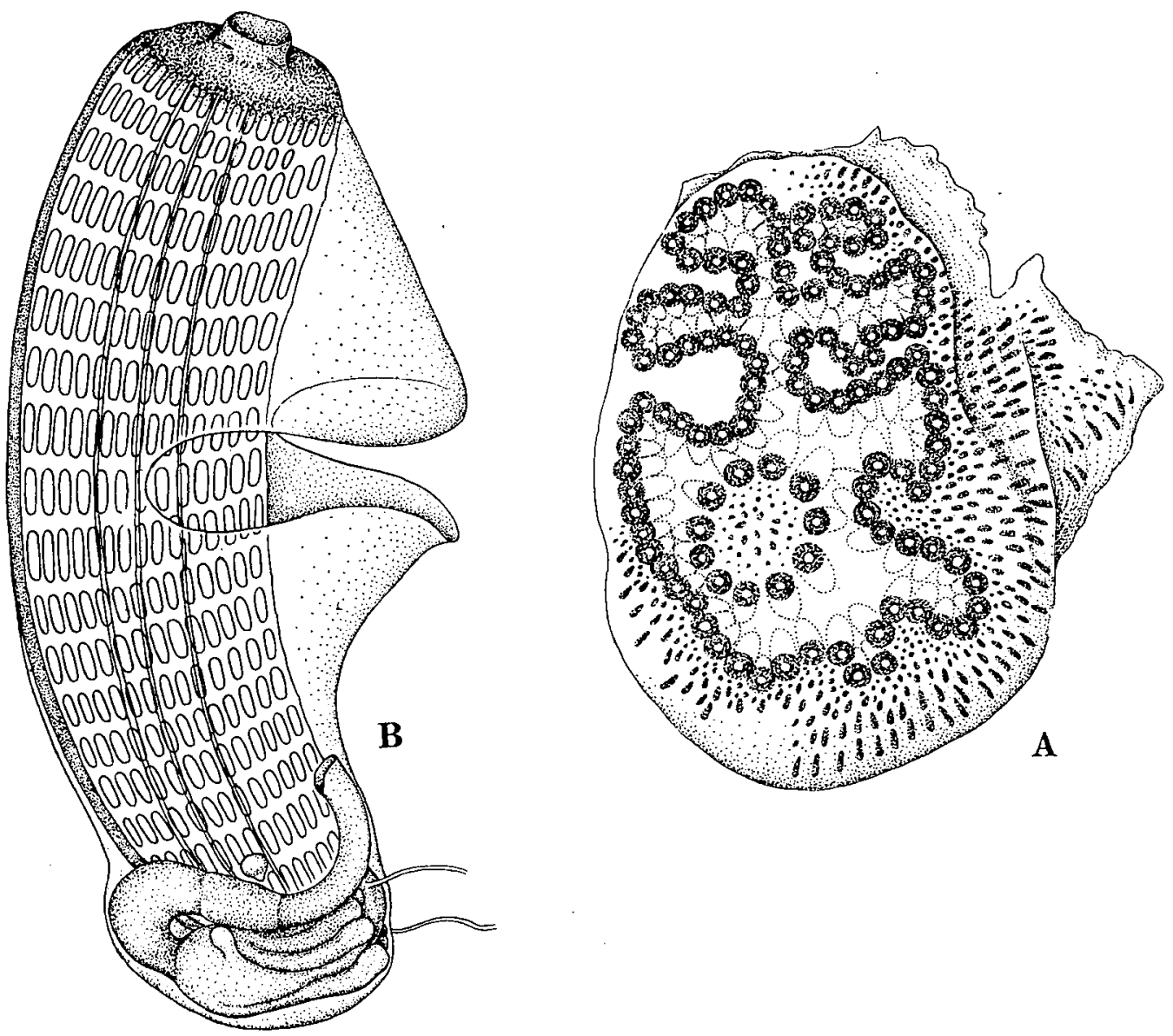

Fig. 1. Botrylloides violareus marginalus Токтока.

A-The smaller, $15 \mathrm{~mm} \times 20 \mathrm{~mm}$, colony. B-Left side of a zooid from the larger colony.

caecum is not so prominent, no special arrangement of vessels is seen around the caecum. The second intestinal loop is evident, but not deep; its axis passes through the cardiac end of the stomach. . The proximal portion of the intestine, just opposite the pyloric caecum of the stomach, is very glandular and looks whitish in preserved specimens. 
The rudimentary gonad is situated on the left side just along the anterior side of the proximal glandular portion of the intestine and consists of a single lobule, and on the right side at the anterior level of the cardiac end of the stomach and consists of one or two small lobules.

\section{Considerations}

At first, the existence of so many stigmatal rows as 18 tempted me to identify these colonies as Botrylloides tyreum Herdman from the tropical West Pacific. Although the colouration of live specimens of $B$. tyreum is still unknown, the superficial resemblance in appearance between the zooid of the present specimens in Text-fig. $1 \mathrm{~B}$ and that of $B$. tyreum shown in Text-fig. 62 in my paper of 1967 (p. 157) is very remarkable. However, the shortening of the second stigmatal row near the dorso-median line in the present specimens differs distinctly from the corresponding structure in $B$. tyreum. Moreover, the relative size and the structure of the alimentary canal differ considerably between the two forms. The alimentary canal is evidently larger in the present specimens than in B. tyreum, neither sharp angle is formed at the proximal end of the intestine nor special arrangement of vessels is found near the pyloric caecum in the present specimens. The rectum is slightly longer in $B$. tyreum. The rudimentary gonad consists seemingly of three lobules in $B$. tyreum. Stigmata are a little more numerous (more than 20 in a row on respective sides) in $B$. tyreum than in the present specimens.

Putting aside the existence of so many stigmatal rows, the structure of zooids of the present specimens given above conforms essentially to that of Botrylloides violaceus Ока. In the specimens of $B$. violaceus marginatus from the Palau Islands the stigmatal rows are 12-14, and this can be continuous to 15-18 stigmatal rows in the present specimens. In the type of $B$. violaceus marginatus, there are a pair of minute dark pigment spots near the distal end of the atrial languet, but such pigment spots are missing in the present specimens. In spite of this difference, the present specimens may safely be identified as $B$. violaceus marginatus.

The very important question is whether or not the taxon marginatus is included in $B$. violaceus. Now the range of the stigmatal rows extends from 12 to 18 in marginatus, at least the median of the range is much higher in this taxon than in violaceus proper. Once OKa tried to define some colour varieties of B. violaceus (OKa 1927), however, those varieties suggested by him are seemingly to be treated more properly as genetical races rather than taxonomical varieties, as in the case of Botryllus schlosseri (PALlas) studied mainly by Italian scholars. I have separated a greenish form as a distinct species, Botrylloides viride Tokioka, from Botrylloides violaceus (Токіока 1964), because the distribution of the colonies of this colour type is confined to the wet lower level of the intertidal zone of the rocky shore facing the open sea and exposed to rough waves and swells. The taxon marginatus externally definable by its striking colour pattern 
is very peculiar in having so many stigmatal rows, and moreover its distribution is seemingly correlated with the circumstances which allow the mass growing of reef corals. Then marginatus might had better be treated as a distinct species. The present status of marginatus is, however, retained till more crucial data are gained about its distribution.

\section{REFERENCES}

OKA, A. (1927). Zur Kenntnis der japanischen Botryllidae (Vorläufige Mitıeilung). Proc. Imp. Acad., Vol. 3, No. 9, pp. 607-609.

Tокіока, T. (1953). Ascidians of Sagami Bay. pp. 241-243, Pl. 3, figs. 1-2; Pl. 44, figs. 1-5; Pl. 45, figs. 1-4.

(1964). Contributions to Japanese ascidian fauna XXI. Botrylloides viride n. sp., a new greenish compound ascidian from the vicinity of Seto. Publ. Seto Mar. Biol. Lab., Vol. 12, No. 4, pp. 281-283, 1 text-fig.

(1967). Pacific Tunicata of the United States National Museum. U.S. Nat. Mus. Bull. 251, pp. 156-162, text-figs. 62-64.

VAN Name, W.G. (1918). Ascidians from the Philippines and adjacent waters. U.S. Nat. Mus. Bull. 100, Vol. 1, Part 2, pp. 111-112, text-fig. 67. 